\title{
All Politics is Local ... Except When It Isn't: \\ The Campaign for the 3rd Congressional District in Pennsylvania
}

Daniel M. Shea and Stephen K. Medvic

In an era when the vast majority of officeholders who seek reelection win (and typically do so by large margins), the rare defeat of an incumbent is a critically important phenomena. In the Third Congressional District of Pennsylvania, a political neophyte - Kathy Dahlrymple (D) — knocked off Phil English (R), a smart, aggressive, 14-year incumbent. Part of the story is the national tide of change, sparked by the presidential campaign of Barack Obama. As a result, the Republican incumbent had no choice but to play defense. But another piece of the tale is the experience of the challenger, which provided her with a non-traditional, but crucially important source of support. Still another layer is the strategies and tactics of both candidates. No two campaigns are ever the same, and the story of the 2008 contest in Pennsylvania's Third Congressional District was certainly unique.

\section{The Context}

\section{The District}

Pennsylvania's Third Congressional District sits in the northwest corner of the state. The district extends from Lake Erie south to Butler and Armstrong Counties and at its southernmost point is roughly 20 miles north of Pittsburgh (see Figure 1). Though 42 percent of the district is rural, there is also a significant industrial influence, particularly in the district's major city, Erie, which is Pennsylvania's fourth most populous city. The result is a district that is more blue-collar (30.7 percent) than the rest of the state $(25.2$ percent) and one with a median income $(\$ 35,884)$ of roughly $\$ 4,200$ less than the state as a whole (Barone and Cohen 2007, 1393; 1374).

Politically, the district leans Republican. In 2000, 51 percent of the voters in the Third District supported George W. Bush as did 53 percent in 2004. In both cases, Mr. Bush's vote totals were five percentage points higher in the Third District than were his statewide totals. Though Erie and

DANIEL M. SHEA is a professor of political science at Allegheny College. STEPHEN K. MEDVIC is an associate professor of government at Franklin and Marshall College.

The American Review of Politics, Vol. 30, Summer, 2009: 173-187

(c)2009 The American Review of Politics 
174 | Daniel M. Shea and Stephen K. Medvic

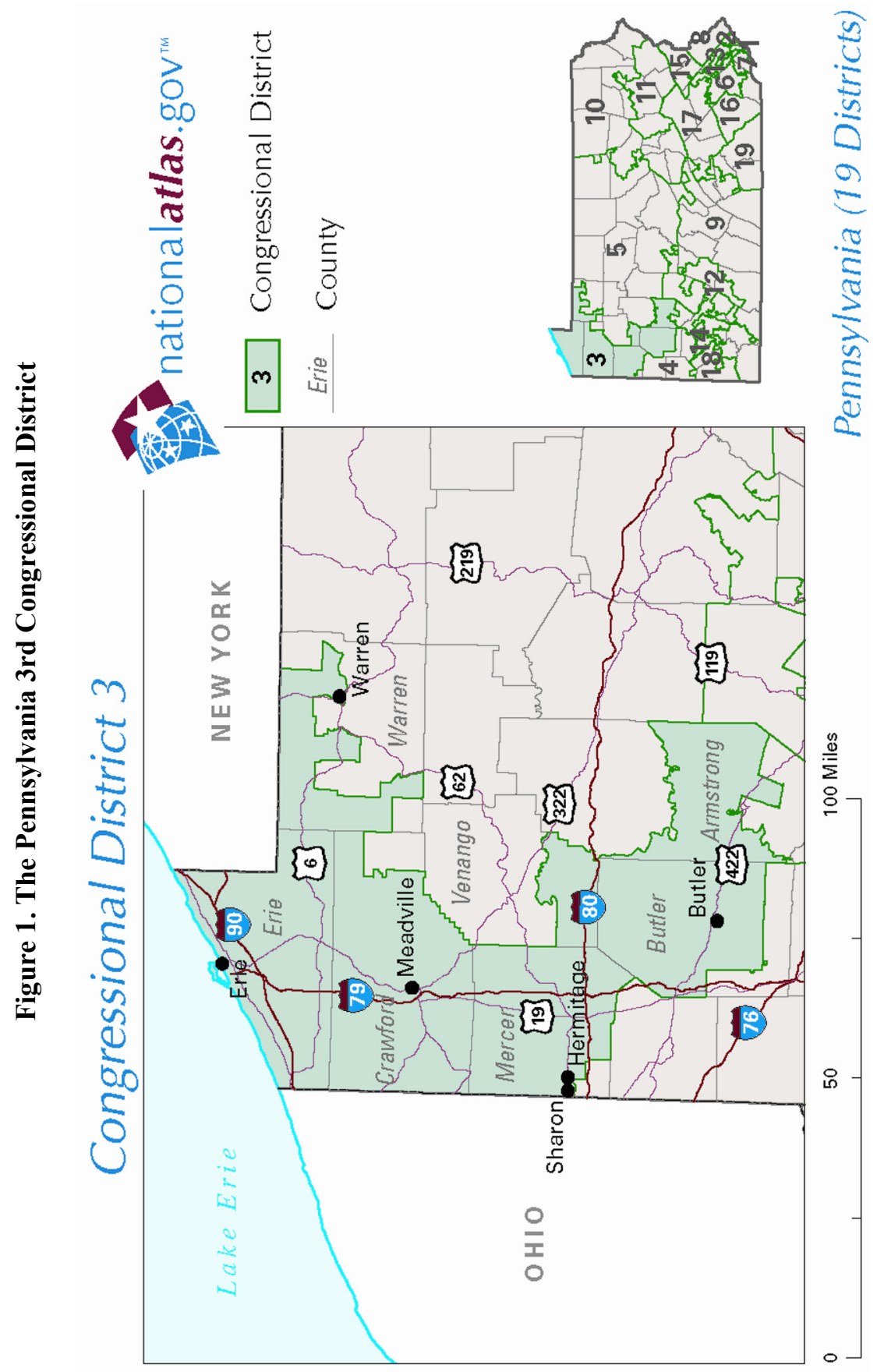


Mercer Counties are predominantly Democratic, the Democrats in this district are relatively conservative. The combination of conservative, bluecollar voters with rural voters explains the Republican tilt to the district, but also suggests an opportunity for Democratic candidates in the mold of Senator Robert Casey, Jr.; that is, those who are economically progressive and socially conservative.

\section{The Candidates}

\section{The Incumbent: Phil English}

Republican incumbent Phil English was first elected to the House of Representatives in 1994 by a narrow victory in which he garnered just under 50 percent of the vote (the Democrat netted 47 percent and an Independent candidate pulled in three percent). It was widely reported that during the 1994 campaign English had pledged to serve only six terms in Congress, though he denied making such a pledge.

In his first reelection contest, English survived another close race, edging out Democrat Ron DiNicola 51 percent to 49 percent. Beginning in 1998, however, he won four consecutive races with at least 60 percent of the vote. In the midterm election of 2006 - a difficult year for the GOP in which fellow western Pennsylvania Republicans Melissa Hart (Fourth Congressional District) and Rick Santorum (Senate) lost reelection bids-English's vote share dropped to 54 percent against a challenger who was vastly outspent. After several years of comfortable victories, English appeared to be on relatively thin electoral ice.

Through 2006, it could reasonably be said that Phil English's voting record was reliably conservative. His ratings from the American Conservative Union (ACU) for 2005 and 2006 were 88 (100 being most conservative) and 80, respectively; the liberal Americans for Democratic Action (ADA) gave him scores of 5 (100 being most liberal) and 15 in those same years. His party unity scores (calculated by $C Q$ Weekly) were 93 percent and 90 percent in 2005 and 2006. Finally, he supported President Bush's position on legislation 85 percent and 95 percent of the time in those two years.

Perhaps in response to a reelection contest in 2006 that was closer than it should have been, English's voting record became noticeably more moderate in the 110th Congress. His ACU scores dropped (that is, became less conservative) to 64 and 52 in 2007 and 2008 and his ADA scores rose (or became more liberal) to 40 and 65 . His party unity scores also fell to 78 percent and 82 percent in 2007 and 2008 and he supported President Bush only 50 percent and 44 percent of the time in those years respectively (see Table 1 for a summary of these trends). 
Table 1. Representative English's Vote Scores, 2005-2008

\begin{tabular}{lrccc}
\hline & 2005 & 2006 & 2007 & 2008 \\
\hline ACU Score & 88 & 80 & 64 & 52 \\
ADA Score & 5 & 15 & 40 & 65 \\
Party Unity Score & 93 & 90 & 78 & 82 \\
Presidential Support Score & 85 & 95 & 50 & 44 \\
Source: The 2005 and 2006 ACU and ADA scores are from Barone and Cohen (2007, 1392); 2007 \\
and 2008 scores are from the ACU and ADA websites. Party unity and presidential support scores \\
are found in the various "vote studies" conducted by CQ Weekly and published in late December or \\
early January each year.
\end{tabular}

With a seat on the powerful Ways and Means Committee, English could claim a significant amount of clout in the House for his constituents. He certainly worked hard to protect their interests, even if that meant occasionally disagreeing with his party. For instance, he supported an increase in the minimum wage and home heating subsidies for low-income families.

Though he voted for the Central America Free Trade Agreement, he did so only after certain concessions were in place and he generally considered himself a supporter of "fair trade." As such, he was willing to support tariffs on imports from China and Vietnam, a popular position in Northwest Pennsylvania. As chair of the Steel Caucus in the House, he was also a staunch defender of the steel industry. This was manifested by his support for import quotas for steel and his efforts to stop Korea from "dumping" (or using predatory pricing for) steel pipe and tubing (Barone and Cohen 2007, 1394).

Following the 2006 midterm elections, English hoped to enter the ranks of Republican leadership in the House. To do so, he made a bid to become chairman of the National Republican Congressional Committee (NRCC). Though that bid was unsuccessful, English was tapped to chair an NRCC task force devoted to erasing the campaign committee's $\$ 14.4$ million debt. ${ }^{1}$

Outsider observers, such as a few local political scientists and several of the beltway handicappers such as Charlie Cook, seemed reluctant to tag English as vulnerable at the outset of the 2008 campaign. He was smart, aggressive, well-positioned on key committees, well-financed, and a moderate in a moderate district. The Cook Political Report, for example, suggested the Third District was "solidly Republican" even after Dahlkemper swamped her primary election opponents. This was likely because traditional wisdom says that incumbents lose due to overt deficiencies and glaring missteps (to be fair, Cook's assessment slowly changed as the campaign progressed.) As noted by a prominent campaign strategist some time 
ago, "Deadly sins of incumbents include excessive absences, numerous junkets, and bloated office budgets, misuse of public funds, cronyism, and voting for taxes" (Brookover, as quoted in Shea and Brooks 1995, 21). This was not Phil English; his problems did not seem obvious or significant.

\section{The Challenger: Kathy Dahlkemper}

Kathy Dahlkemper was the first woman from Northwestern Pennsylvania ever elected to Congress in her own right (i.e., not filling a spot held by a deceased husband). She was able to beat three good candidates in a heated primary - all by double digits - and to knock-off an attentive 14-year incumbent in the general election. One would assume that her background was a key factor in her victory, and it was, but not in the conventional sense.

Indeed, it is difficult to pin Kathy Dahlkemper's background into categories common among successful challengers. For one, she had never held public office prior to running for Congress. She never expressed any interest in public life prior to 2007. In fact, she had never spoken up in any public forum (letter to the editor, open city council meetings, etc.) about a public policy question, nor had she been a robust supporter of any other candidate or public figure. No one in her immediate or extended family could be called "political" and she was not the sponsored candidate of any prominent public official.

Along similar lines, Dahlkemper was not an active member in local party politics. The Erie County Democratic Committee is a viable organization, boasting several dozen active members and undertaking numerous functions throughout the year. Dahlkemper never attended party meetings and rarely took part in these events.

There was no issue or set of ideological concerns that propelled her candidacy, as is often the case with challengers. In the fall of 2007, before she had entered the race, one of the authors of this chapter (Shea) was invited to have lunch with her. Dahlkemper was interested in finding out more about the rigors of a competitive congressional campaign, as well as the broad parameters of being a member of Congress. During their 90 minute conversation Dahlkemper noted concerns about the war in Iraq, our nation's dependence on foreign oil, the loss of jobs in the region, and what she believed to be a less-than adequate health care system. But no particular issue or a deep ideological agenda seemed at the heart of her potential candidacy. Instead, there seemed to be a general belief that it was time for new leadership and that she might have something to give. She was also concerned with the general direction of the community and about the "future for our children." As she explained it, several friends had made passing comments that she would make a good member of Congress, and this caught her 
attention. She had completed her work raising her five children, and the idea of running for Congress kept surfacing.

Nor was she wealthy, ready to conduct a robust self-financed race, as is generally the case with successful challengers. She and her husband Dan own a landscaping business, with about ten employees during peek seasons. There was no significant pool of resources from which Dahlkemper expected to draw. Nor was she a principal figure in business circles. The Dahlkempers were known and respected in the Erie business community, but there is little evidence that Kathy or Dan were leaders in that realm.

In short, Kathy Dahlkemper did not have a political base, a pool of resources to draw upon, a sponsor, or a deep connection to the local party organization. And her candidacy was not driven by a pressing issue or an ideological agenda.

So how did her background help defeat an entrenched incumbent? What resources was she able to draw upon? For one, she had a much larger base than most outside observers understood. Her deep community roots sprang from an intimate tie to the Erie Roman Catholic Dioceses. She and her family faithfully attended church and through the decades Dahlkemper had taken on numerous leadership roles in the church. The most important of these activities was her position as marriage encounter coordinator.

The Erie Dioceses, as with most Catholic dioceses across the country, regularly holds marriage encounter weekends for parishioners. As coordinators, Dan and Kathy Dahlkemper steadily broadened their network of intimate friends - not mere acquaintances, but dear friends. They were known and well-liked throughout Northwest Pennsylvania. This created a steadfast base of supporters that any local elected official would covet. And, unlike the followers of most politicians, Dahlkemper's base was bipartisan; many of her Catholic friends were conservative Republicans. Thus, by the time she was gearing-up for her campaign, Dahlkemper was better known than each of her primary election opponents even though they were elected officials and/or leaders in the Erie legal community. We might say that her strength sprang from a veiled base, rather than an overt group of partisan supporters.

Worth brief mention, Dahlkemper's name identification was buffeted from the recurrent television advertisements for Dahlkemper Jewelry Connection, a vibrant small business in Erie. The two families are related, though only distantly (as third cousins). Nevertheless, for most residents in Northwest Pennsylvania the name "Dahlkemper" was rather familiar.

A less tangible, but nonetheless critical resource for Dahlkemper was her understanding of the mood of the community. Having lived nearly all of her adult life in Erie, and having raised five children and owned a small business in the area, she had an intuitive sense of how things were going. 
This was quite obvious in several pre-primary conversations with Shea when she articulated a growing unease with Phil English. Dahlkemper insisted that the district needed a change in leadership.

There is one other resource that may have proved quite helpful. Jim Murphy, a veteran of New York State electoral politics, once commented that the number one characteristic in successful challengers is the steadfast commitment to winning. "When you are looking for challengers to back," noted Murphy, "the depth of their conviction says as much as anything. Successful challengers have a big heart, and are not afraid to show it" (as quoted in Shea and Brooks, 1995, 23). By all accounts, Dahlkemper was of this sort of candidate. She considered her run for months, carefully charting what it would take and her own level of commitment. Once she made the decision, she worked tirelessly. She took very few days off from long before the primary until November, and on most days put in long hours. Given the nature of her employment, Dahlkemper was able to campaign full time. She made the most of it; she certainly had heart.

\section{The Campaign}

\section{English: Trying to Find the Right Message}

Phil English's reelection strategy had remained essentially the same through the years. First, he would take care of the district. As member of the majority for most of his time in the House, and as a member of important committees, including Ways and Means, English was afforded hefty earmarks. He also kept busy on legislation, sponsoring some 357 bills between 1995 and 2008, of which 5 were successfully enacted into law. He was skilled at advertising, which included robust use of the franking privilege and copious press releases. In 2006, for example, English sent out mailings from his congressional office totaling some $\$ 73,360{ }^{2}$ He would also tout his moderate voting record. English was a skillful fundraiser, too. His ability to amass a huge war chest scared off many potential opponents, often leaving the field to weaker challengers.

Finally, and perhaps most importantly, English skillfully used his massive resources to create a narrative about his opponents. This followed a major axiom of campaigning: define the opponent before she can define herself. A good example of English's adherence to this rule was his campaign against Stephen Porter, who ran against English in 2004 and 2006. Few expected Porter to mount a serious campaign, having few roots in the community and very modest resources. Nevertheless, English leveled a barrage of negative campaign ads against the retired art professor early in both campaigns. Again and again, over the airways and through direct mail, 
English portrayed Porter as a radical, with irrational, if not dangerous, ideas about public policy. Regardless of whether the attacks were founded, the volume of attacks was devastating; Porter stood little chance. It was like watching a professional football team play against a high school squad.

In short, English's reelection strategy had always been the traditional route for most incumbents: take care of the district; be visible to voters; amass a huge war chest; and define the opposition early in the campaign so that they could never recover. Money from outside groups, a critical party of most challengers' campaigns, would sit on the sidelines. On the night that Dahlkemper won the Democratic primary, English was candid about the route to victory he would take in 2008: follow the path of prior campaigns. ${ }^{3}$

Things, however, took a different turn. For one, English's vote total in 2006 against Stephen Porter was surprisingly small—just 54 percent. Porter was a weak candidate with very modest resources (netting about $\$ 81,000$ for his 2006 race). This, combined with a growing sense that Republicans were out of favor nationally, lead to a hotly contested primary election on the Democratic side. That is to say, many Democrats smelled blood in the water and were itching for a chance to challenge English. Still, the primary was cordial and when it was over all the candidates rallied around the winner. Dahlkemper also proved somewhat adept at raising early money. While her fundraising never matched English's (in the end she raised about one-half English's total), by mid-spring she had raised more than Porter's total in 2006.

Most significantly, English's efforts to define Dahlkemper did not seem to work. His strategy to label her as a "radical liberal," the approach used against Porter, did not seem to resonate because Dahlkemper was a pro-life, pro-gun, small business owner. Having few policy-centered lines of attack, several early negative ads in support of English, which were sponsored by the NRCC, suggested Dahlkemper had "wacky" environmental ideas. ${ }^{4}$ One ad even featured a dogsled, suggesting that if his Democratic opponent had her way few would have gasoline to drive cars. There is little evidence that this worked. As noted by one of Dahlkemper's campaign operatives, "the polling hardly moved, and our positives remained much higher than English's throughout the course of the campaign.",

Thus, English's strategy of offering himself as the moderate, common sense alternative - even if voters were not crazy about his party - stalled. By early fall it was clear that the English team understood this and a new approach was floated. During the first debate, held at Allegheny College in early October, English outlined the new strategy in his opening statement. "This district," he said, "needs a change, and I intend to be the agent of change." He went on to suggest that only those who understand the complexity of the legislative process, the ins-and-outs of Congress, could bring 
meaningful change to the district. In other words, English was trying to become the change candidate; given the resonance of the "change" theme in Barack Obama's campaign, and given only about 20 percent of Americans thought the country was headed in the right direction, one can understanding the attractiveness of this new message. Only an experienced legislator can really know how to change the system, but it seemed rather odd coming from a 14-year incumbent who originally ran for Congress supporting term limits.

At the end of the campaign the strategy continued to shift. It could be seen in his television advertisements, press releases, and in the final debate at the local public radio station. The message from English now was that he had delivered for the district, time and again, and the community would suffer if they lost their leader in Washington. For example, in the spring of 2008, he claimed credit for helping provide nearly $\$ 1$ million in federal funds for sand restoration at Presque Isle State Park, the largest tourist attraction in the district. ${ }^{7}$ As it became clear that Obama would likely win the presidency, English also made the pitch that Republicans should be sent back to the House in order to check radical policy changes. A final line of attacks was leveled against Dahlkemper, this time attempting to paint her as wealthy and out of touch. The focus of the English campaign seemed muddled. Phil English and his supporters seemed to be throwing everything at the wall with the hope that something would stick. Likely, the inconsistency in message was due to never being able to mount a line of attack against his opponent. As his polling numbers stalled and as the attacks continued, English scrambled for any theme that would take.

\section{Dahlkemper: "You Know Me!"}

Early polling showed the race close-with Dahlkemper perhaps a few points ahead of English. Unlike most challengers, there was no hill to climb for the Democrat, but instead a lead to maintain. However, even when the results of this poll were released to the media and reported on in June showing that Dahlkemper had the support of 41 percent of likely voters, English at 40 percent, and 19 percent undecided, ${ }^{8}$ groups that might have been willing to spend outside money, surprisingly continued to hedge their bets and wait on the sidelines.

Early on, the Dahlkemper campaign focused on building the candidate's credentials and local ties. A series of "bio" mailings and television spots focused on her community roots and her experience as a mother and small business owner. The message was simple: You know Kathy Dahlkemper; she's one of us. Dahlkemper noted, "I had connections with people from all over the district—-through my life.", 
Perhaps concerned that their opponent would slowly rise in the polls as the election drew near, or maybe as a means to offset the attacks being leveled against their candidate, near the end of the summer the Dahlkemper campaign shifted to attack ads against English. Generally, this was a two pronged approach. First, in keeping with the theme many Democrats employed across the nation, the idea of "change" was pushed by the candidate. It was time for Phil English to step aside. Dahlkemper pounded this theme at events, press conferences and debates. Second, a series of attack ads sponsored by the Democratic Congressional Campaign Committee (DCCC) and American Federation of State, County and Municipal Employees (AFSCME) suggested English was more concerned with protecting "special interests" and "Wall Street speculators" than with protecting the residents of Northwest Pennsylvania. The message here was simple: English was out of touch, failing to protect average citizens. Democratic committee ads "were able to take on the opposition while allowing us to stay focused on the positive message of change and vision for the district," said Tina Mengine, Dahlkemper's campaign manager. Moreover, she noted, "because we have no input into these ads nor do we know about them in advance, each ad that ran was a surprise and usually very welcome" (Perna 2009). As Mengine notes, this type of activity is often viewed positively by candidates' campaigns because while the party or outside group hammers away at the opponent, the candidate can remain untainted by the charge of "negative" campaigning.

When pressed to explain the overall strategy of the Dahlkemper campaign, another staffer suggested it was "all about fight[ing] off attacks and keeping our lead." Also, "Kathy was much more popular than most of us understood. The attack ads didn't stick because they [the voters] knew her." 10

Dahlkemper's strategy also focused on geography. As noted above voters in the Third District lean Republican, but it varies greatly from one county to the next. Dahlkemper's campaign understood that if they could carry Erie County, roughly 50 percent of the district, by a large margin and hold their own in the other Democratic county, Mercer, they could pull it off. This proved to be a wise route, as she won Erie with nearly 57 percent of the vote and Mercer County with nearly 52 percent, but lost every other county.

Finally, it is likely that Dahlkemper benefited from support among women voters. The nuances of identity politics are complex and hard to fully discern when exit polling is unavailable, but it is clear that Hillary Clinton was quite popular in the Third District, especially among Democratic women. In the congressional primary, held the same day as the presidential primary, the margins of victory for Clinton and Dahlkemper were highly 
correlated throughout the district. That is, both candidates had massive wins in the rural counties - Crawford, Venango, Butler, and Mercer. In Erie County the race between Clinton and Obama was closer, as was the margin of victory for Dahlkemper. Did this carry over to the general election? It is hard to say, but in a year when "change" dominated the political landscape (an issue discussed in greater detail below) Dahlkemper, the first women candidate for Congress from this area in decades, seemed to fit the bill.

\section{Party Committees and Interest Groups}

Faced with a serious challenge, English raised nearly \$2.7 million, which was twice as much as his Democratic opponent. Though Dahlkemper's $\$ 1.3$ million was an impressive fundraising haul for a challenger, her Democratic allies appear to have been concerned about the spending disparity between the candidates. Late in the summer of 2008, the DCCC added Dahlkemper to their "Red to Blue" program of targeted House races. ${ }^{11}$ In the end, their financial commitment to Dahlkemper amounted to nearly $\$ 1.6$ million in independent expenditures, a total that dwarfed spending by all other outside groups. Half that amount was spent in support of Dahlkemper while the other half was used for attacks against English.

AFSCME also spent independently in this race. In fact, AFSCME spent almost half a million dollars - all of which was spent opposing Englishwhich was more than any other group, save the party committees. Of course, a number of Democratic leaning interest groups endorsed Dahlkemper. Those endorsements meant not only financial contributions to her campaign, but the commitment of volunteers for canvassing and get-out-the-vote efforts. The support of organized labor is particularly valuable in this regard and Dahlkemper lined up endorsements from nearly all of the major unions including the ALF-CIO and the United Steelworkers.

As an incumbent, English was able to raise plenty of money, but his vulnerability and the DCCC's commitment to Dahlkemper worried the NRCC. As early as September 10, the NRCC paid for polling in the Third District, one of only two incumbent-held seats in which they were polling at that time. ${ }^{12}$ The NRCC ad criticizing the Democratic challenger for her "wacky" ideas about energy-its first ad of the cycle - was yet another sign that English was high on the party's list of incumbents to protect. ${ }^{13}$ The DCCC responded to this ad immediately, with one accusing English of supporting the privatization of Social Security. ${ }^{14}$

English also received more money from Republican leadership PACs than all but two other Republican incumbents, an indication that his colleagues recognized the trouble he faced. ${ }^{15}$ For its part, the NRCC spent $\$ 776,828$ to help English and virtually all of that money was spent attacking 
Dahlkemper. Other groups that spent independently on the Republican side, including the National Rifle Association $(\$ 91,694)$ and the American Medical Association $(\$ 200,338)$, did so entirely in support of English (rather than against Dahlkemper). Despite the assistance from the party and other outside groups, English was in serious trouble by the end of October. With just about two weeks left in the campaign, Politico reported that the GOP was "all but writing off" English's seat. ${ }^{16}$ Indeed, the last independent expenditure by the NRCC against Dahlkemper was made on October $24 .{ }^{17}$

When all was said and done, Dahlkemper's allies nearly eliminated the financial gap between her and the Republican incumbent. Democratic spending, including Dahlkemper's, amounted to $\$ 3,496,614$; Republican spending totaled $\$ 3,929,721$ (see Table 2). Clearly, the independent spending efforts in support of Dahlkemper were critical to her ability to mount a serious challenge. The DCCC, in particular, was invaluable. As Dahlkemper acknowledged, "Having support from the party was very helpful, just in letting me compete on a level playing field" (Perna 2009). Without their assistance, it is quite possible that the outcome of this race would have been different.

Table 2. Spending by Both Sides in Pennsylvania's Third Congressional District Race

\begin{tabular}{lcccc}
\hline & Party Committees $^{\mathrm{a}}$ & Interest Groups & Candidates & Total \\
\hline Dahlkemper & $\$ 1,592,099$ & $\$ 591,276$ & $\$ 1,313,239$ & $\$ 3,496,614$ \\
English & $\$ 858,300$ & $\$ 411,450$ & $\$ 2,659,971$ & $\$ 3,929,721$ \\
& & & \\
ancludes coordinated expenditures by the Pennsylvania Democratic Party (for Dahlkemper) and the \\
Republican National Committee (for English). \\
Source: Center for Responsive Politics, "2008 Race: Pennsylvania District 03, Independent Expen- \\
ditures," http://www.opensecrets.org/races/indexp.php?cycle=2008\&id=PA03 (accessed March 18, \\
2009); figures updated by a search of disclosure data for committees at the Federal Election Com- \\
mission, http://www.fec.gov/finance/disclosure/disclosure data_search.shtml (accessed March 18, \\
2009).
\end{tabular}

\section{Lessons Learned}

Incumbents lose, but not often. The conventional wisdom is that English got caught up in the national anti-Republican tide. All politics is local, except when it is not (we might say). He was an attentive, active representative, but he could not weather the storm against his party and the backlash against George W. Bush. Phil English had no choice but to play defense. 
There is some truth to the conventional wisdom, of course. It is likely that Dahlkemper would not have entered the race if she and others in the district did not perceive a powerful national tide. She calculated that there would be a boost for any Democratic candidate. The strategic politician model played out across the nation in the fall of 2007 (Jacobson and Kernell 1983). Indeed, "strategically sophisticated challengers carefully judge the vulnerability of their opponents ..." (Goldenberg and Traugott 1986, 15). Moreover, strong potential candidates are vastly more likely to run when they see a good chance of winning seems to be have played out in this race (Maisel, Stone, and Maestas 2001).

In addition, outside groups might not have been able to bolster Dahlkemper's efforts if the Democratic advantage had not been as big as it was in 2008. Because there was more energy and excitement among Democrats than among Republicans, the Democratic Party and its allies were flush with money. With more money to spend than their opponents, the Democrats could compete in more races than could the GOP. So the national tide had very practical implications for the resources available on the challenger's side of this race.

But did voters kick their 14-year incumbent out of office simply out of a desire for change? Did Barack Obama's message trickle down to Northwest Pennsylvania and did his coattails pull Dahlkemper along? Perhaps, but one should bear in mind that Barack Obama lost the Third Congressional District of Pennsylvania. He carried Erie County, but was badly beaten in all of the other counties (though he performed better than John Kerry had done in nearly every part of the district). Indeed, Dahlkemper ran ahead of Obama in some counties. In Butler County, for instance, Obama received 35.7 percent of the vote, compared to Dahlkemper's 48.1 percent. ${ }^{18}$ Many scholars have found only modest evidence to suggest a direct connection between national tides and local voting trends (see Jacobson 1987 and 1992, for example). Additionally, if the tide was so strong, how did some Republicans stay afloat? Again, English was a competent, moderate legislator.

Another explanation might be that English ran a poor campaign. Ed Brookover, the former Political Director of the National Republican Senatorial Committee and Regional Political Director of the Republican National Committee once noted, "There is nothing more pleasing, from the point of view of a strategist, than to work against an incumbent who runs the same campaign again and again" (Shea and Brooks, 1995, 24). English surely began his campaign against Dahlkemper the same way that he had confronted other opponents. When that did not work, his campaign appeared to panic and flailed from strategy to strategy until it ended up with a terribly inconsistent message. 
The most likely explanation contains elements of each. There was a tsunami against all GOP candidates and English was in trouble even before the Democratic primary. His team, however, probably surmised that they could survive by relying on their ability to use hefty resources to define the opponent. This would keep outside Democratic money on the sidelines and push voters to see Dahlkemper as too risky. The problem was that attacks on Dahlkemper did not stick. She was too well-known and respected in the district. Over nearly two decades she had broadened her community roots into a solid foundation. She was a political neophyte, but a known neophyte. As months passed and Dahlkemper maintained her strength, her campaign caught the attention of the DCCC, AFSCME, and other contributors. This outside money was critical in helping to neutralize English's last-minute media blitz.

The core lesson of the race, then, is that national trends can shape local contests, but alone they cannot determine the outcome of these races. Other factors such as the quality of the candidates and the effectiveness of their campaigns also matter. For an incumbent free of scandal or controversy to lose, all of these elements must be present. In the Third Congressional District of Pennsylvania in 2008, they were.

\section{NOTES}

${ }^{1}$ John Bresnahan, "House Republicans Help Make a Dent in Party's Debt," Politico, February 19, 2007 http://www.politico.com/news/stories/0207/2827.html (accessed March 18, 2009).

${ }^{2}$ Jerome L. Sherman, "Rep. Murphy is the king of "franking," Pittsburgh PostGazette, May 7, 2007, http://www.post-gazette.com/pg/07127/784003-176.stm (accessed April 15, 2009).

${ }^{3}$ Kevin Flowers, "Dahlkemper Wins Nomination," Erie Times News, April 23, 2008, http://kathydahlkemperforcongress.com/node/107 (accesed April 29, 2009).

${ }^{4}$ Reid Wilson, "GOP on air as Dems drop the hammer," The Scorecard, Politico, October 1, 2008, http://www.politico.com/blogs/scorecard/1008/GOP_On_Air_As Dems Drop The Hammer.html (accessed March 18, 2009).

${ }^{5}$ Michael Burton, personal interview March 17, 2009.

${ }^{6}$ Response to a question in the first debate at Allegheny College, October 12, 2008.

${ }^{7} \mathrm{See}$ http://www.legistorm.com/earmarks/details/member/221/Rep Phil English/ page/1/sort/amount/type/desc.html (accessed April 30, 2009).

${ }^{8}$ Snyder, Matt, "Dahlkemper, English Race Dead Heat, Dem Poll Says," Sharon Herald, July 16, 2008, http://www.sharon-herald.com/local/local story 198220756.html? start:int $=0$ (accessed April 26, 2009).

${ }^{9}$ Perna, Lindsay. 2009. "Dahlkemper Aided by Democratic Committee in Win Over English," News from DC, WSEE.TV Washington Bureau, March 17, http://wsee.tv/ blogs/ washington/?p=58 (accessed March 18, 2009).

${ }^{10}$ Michael Burton, personal interview March 17, 2009. 
${ }^{11}$ Cadei, Emily, "Six More Democratic Candidates to Get Party Help," CQ Politics, August 1, 2008, http://www.cqpolitics.com/wmspage.cfm?docID=news-000002932710 (accessed March 18, 2009).

${ }^{12}$ Reid Wilson, "NRCC polls GOP-held districts," The Scorecard, Politico, September 10, 2008, http://www.politico.com/blogs/scorecard/0908/NRCC_Polls_GOPHeld Districts.html (accessed March 18, 2009).

${ }^{13}$ Reid Wilson, "GOP on air as Dems drop the hammer," The Scorecard, Politico, October 1, 2008, http://www.politico.com/blogs/scorecard/1008/GOP_On_Air_As Dems Drop_The Hammer.html (accessed March 18, 2009).

${ }^{\overline{14}}$ Aaron Blake, "Dems raise stakes on Social Security 'gamble," The Hill, September 30, $2008 \mathrm{http} / /$ thehill.com/leading-the-news/dems-raise-stakes-on-social-securitygamble-2008-09-30.html (accessed March 18, 2009).

${ }^{15}$ CQ Moneyline, "Close Races Draw Leadership PAC Money," CQ Politics, February 9, 2009, http://www.cqpolitics.com/wmspage.cfm?docID=moneyline-000003028016 (accessed March 18, 2009).

${ }^{16}$ Josh Kraushaar and Reid Wilson, "GOP 'goner' list warns of House rout," Politico, October 23, 2008, http://www.politico.com/news/stories/1008/14885.html (accessed March 18, 2009).

${ }^{17}$ This is based on a search of independent expenditure reports for the NRCC at the Federal Election Commission website, http:/query.nictusa.com/cgi-bin/com_supopp/ C00075820/ (accessed March 18, 2009).

${ }^{18}$ Election results can be found on the Pennsylvania Secretary of State's webpage, http://www.electionreturns.state.pa.us/ElectionsInformation.aspx? FunctionID $=0$ (accessed April 15, 2009).

\section{REFERENCES}

Barone, Michael, with Richard E. Cohen. 2007. The Almanac of American Politics, 2008. Washington, DC: National Journal.

Goldenberg, Edie N., Michael W. Traugott, and Frank R. Baumgartner. 1986. Preemptive and Reactive Spending in U.S. House Races. Political Behavior 8:3-20.

Jacobson, Gary C. 1987. The Marginals Never Vanished: Incumbency and Competition in Elections to the U.S. House of Representatives. American Journal of Political Science 31:126-141.

Jacobson, Gary C. 1992. The Politics of Congressional Elections, 3d ed. New York: Harper Collins.

Jacobson, Gary C., and Samuel Kernell. 1983. Strategy and Choice in Congressional Elections, 2nd ed. New Haven, CT: Yale University Press.

Maisel, L. Sandy, Walter J. Stone, and Cherie Masestas. 2001. Quality Challengers to Congressional Incumbents: Can Better Candidates be Found? In Playing Hardball: Campaigning for the U.S. Congress, ed. Paul S. Herrnson. Upper Saddle River, NJ: Prentice Hall.

Perna, Lindsay. 2009. Dahlkemper Aided by Democratic Committee in Win Over English. News from DC, WSEE.TV Washington Bureau, March 17, http://wsee.tv/ blogs/washington/?p=58 (accessed March 18, 2009).

Shea, Daniel M., and Stephen C. Brooks, 1995. How to Topple and Incumbent: Advice from Experts Who've Done It. Campaigns and Elections, June, p. 21-25. 